Article

\title{
Addressing Wildfire Risk in Forest Management Planning with Multiple Criteria Decision Making Methods
}

\author{
Susete Marques ${ }^{1, *}$, Marco Marto ${ }^{1}$, Vladimir Bushenkov ${ }^{2}$, Marc McDill ${ }^{3}$ and José G. Borges ${ }^{1}$ \\ 1 Forest Research Center, School of Agriculture, University of Lisbon, Tapada da Ajuda, 1349-017 Lisboa, \\ Portugal; marcovmarto@isa.ulisboa.pt (M.M.); joseborges@isa.ulisboa.pt (J.G.B.) \\ 2 Research Centre for Mathematics and Applications, University of Évora, Colégio Luís Verney, \\ Rua Romão Ramalho, 59, 7000-671 Évora, Portugal; bushen@uevora.pt \\ 3 Department of Ecosystems Science and Management, Pennsylvania State University, \\ 310 Forest Resources Building University Park, State College, PA 16802-4301, USA; mmcdill@psu.edu \\ * Correspondence: smarques@isa.ulisboa.pt; Tel.: +351-21-365-3366
}

Academic Editor: Marc A. Rosen

Received: 30 November 2016; Accepted: 14 February 2017; Published: 18 February 2017

\begin{abstract}
Wildfires impact the outcomes of forest management plans. Addressing that impact is thus critical for effective forest ecosystem management planning. This paper presents research on the use of multiple criteria decision making (MCDM) methods that integrate wildfire risk in planning contexts characterized by multiple objectives. Specifically, an a posteriori preference modeling approach is developed that adds wildfire criteria to a set of objectives representing ecosystem services supply values. Wildfire risk criteria are derived from stand-level wildfire occurrence and damage models as well as from the characteristics of neighboring stands that may impact wildfire probability and spread. A forested landscape classified into 1976 stands is used for testing purposes. The management planning criteria include the carbon stock, harvest volumes for three forest species, the volume of the ending inventory, and resistance to wildfire risk indicators. Results show the potential of multiple criteria decision making methods to provide information about trade-offs between wildfire risk and the supply of provisioning (timber) as well as regulatory (carbon) ecosystem services. This information may contribute to the effectiveness of forest ecosystem management planning.
\end{abstract}

Keywords: multiple criteria decision making methods; Pareto frontier methods; wildfire risk criteria; ecosystem services

\section{Introduction}

The supply of ecosystem services from forested landscapes often relies on the spatial distribution of conditions and activities across several stands. Management activities on one stand often influence the level and quality of ecosystem services that are provided by adjacent stands. Therefore, the ideal provision of ecosystem services from landscapes that encompass multiple stands often requires the consideration of both temporal and spatial interactions among stand-level management options. Forest ecosystem planning is especially complex, with multiple, often competing outputs and goals. Effective multi-objective management planning and development of targets for the supply of diverse ecosystem services relies on the availability of sound trade-off information [1]. There is, therefore, a need for tools that can provide this type of information during the process of developing forested landscapes management plans.

The literature reports the use of criteria to address the supply of provisioning and regulatory ecosystem services in multiple-objective forest ecosystem management planning [2,3]. It further reports 
the use of multiple criteria decision making (MCDM) methods to provide information about trade-offs among those criteria (e.g., [1,4-6]). Other studies (e.g., [7-10]) have focused on the integration of wildfire risk in forest management planning and on the trade-offs between strategies designed to address that risk. This research is often focused on a limited number of forest management strategies, however. To our knowledge, no approach has been developed that uses wildfire risk indicators that can be computed using easily measured inventory data based on forest characteristics that can be controlled by forest managers to provide information about trade-offs between wildfire risk criteria and the supply of other ecosystem services in contexts with a very large number of management alternatives. Yet each year forest fires destroy about 500,000 ha of vegetation in Europe, predominantly in the Mediterranean region [11]. Forest fires have social, ecological and economic costs. In Europe, Portugal has the highest frequency of fire ignitions and burned area [12,13]. In addition, the number of fires and burned area has been increasing, as has the number of large and catastrophic fires [14,15]. Forest owners, as individuals or through associations, need support in dealing with this issue in order to reduce the probability and expected value of losses due to fires. The improvement of fire prevention is therefore vital, and the need for tools that forest managers can use to analyze the trade-offs between wildfire risk and the supply of ecosystem services is apparent. That analysis requires the development of more effective wildfire risk criteria.

Bar Massada [16] observed that the definition of fire risk and hazard differs from study to study. According to the definitions proposed by Hardy (2005) [17], fire risk is defined as the chance that a fire might start, whether by natural or human causes (e.g., ignitions), and fire hazard is defined as the potential fire behavior for a fuel type, regardless of the fuel moisture content, which may be influenced by temporary weather conditions. González et al. (2006) [18] proposed the term endogenous risk, and Jactel et al. (2009) [19] proposed the term hazard likelihood. For other authors [20,21], fire risk results from the combination of (i) hazard, or the probability of ignition and the probability of fire spreading across the landscape; and (ii) vulnerability, expressed as potential damage to forests, vegetation, houses, and other buildings due mainly to the intensity of the fire. Different approaches can be used to assess wildfire risk, and recent studies have shown that many indicators of wildfire occurrence (ignition) [12,13], fire recurrence (frequency) [22-26], and area burned can be identified [14,26].

In some studies (e.g., $[27,28])$, research on forest wildfire behavior and indicators has been used to help forest managers identify critical areas so that stands within those areas can be treated to increase their resistance to fire. Critical areas can be used to identify ways to reduce the spatial continuity of the forest with regard to fire spread within the context of the economic viability of a landscape-level forest management plan (e.g., [27-29]). This can reduce the costs and increase the efficiency of preventive measures by establishing priority areas to treat [30]. Several studies have developed models and indicators to measure fire risk as well as vulnerability and resistance to fire. However, these models include variables that either cannot be controlled by managers-e.g., topography, climate, land use and historic fire data [31-38]—or that are inappropriate for long-term planning problems, as they require variables that are continuously changing, such as wind speed and fuel moisture, and/or that are not amenable to be used as management planning criteria by MCDM methods (e.g., [11,39-50]). Furthermore, the level of detail and computational intensity of these models is not practical for planning contexts characterized by a large number of management alternatives.

This research uses the indicators developed by [51] to define a set of wildfire risk criteria. Some of these indicators take into account stand-level wildfire occurrence and damage models that have as predictors biometric variables that are easy to acquire and that are controllable by managers [22-24,50,52-54]. Others also account for stand geometry (e.g., shape and size) and topology (e.g., spatial context) in order to address wildfire spread concerns. The wildfire risk criteria are tested within an a posteriori MCDM approach so that the decision maker is not required to set targets for criteria before being informed of trade-offs among ecosystem services. A large-scale problem encompassing 1976 stands and 430,110 stand-level prescriptions is used for testing purposes. Thus, rather than using discrete a posteriori MCDM-e.g., Analytic Hierarchy Process AHP [55-57] or 
PROMETHEE and ELECTRE III [58] —-that are suited for problems with fewer alternatives, this research uses a Pareto Frontier approach (e.g., [1,4,5,59]).

\section{Material and Methods}

\subsection{The Study Area}

The Zona de Intervenção Florestal (ZIF) Paiva and Entre-Douro e Sousa (ZIF_VS) is located in northwestern Portugal in a rural area with a Mediterranean climate with an Atlantic influence. The ZIF_VS area extends over 14,388 ha and was classified into 1976 stands. The criteria used to classify the landscape included the land use (e.g., agriculture land, forestland), the forest species composition (e.g., pine, eucalypt, chestnut), the stand age, and the site index. The area is dominated by pure eucalypt (Eucalyptus globulus Labill) stands and mixed stands of eucalypt and maritime pine (Pinus pinaster Ait.) - about $66 \%$ and $33 \%$ of the ZIF_VS area, respectively. The remaining area is occupied by hardwoods, mostly chestnuts. Eucalypt pulpwood and maritime pine sawlogs are the primary ecosystem services provided by ZIF_VS. Other products and services include hardwood (chestnut) sawlogs and carbon storage [60] (Figure 1).

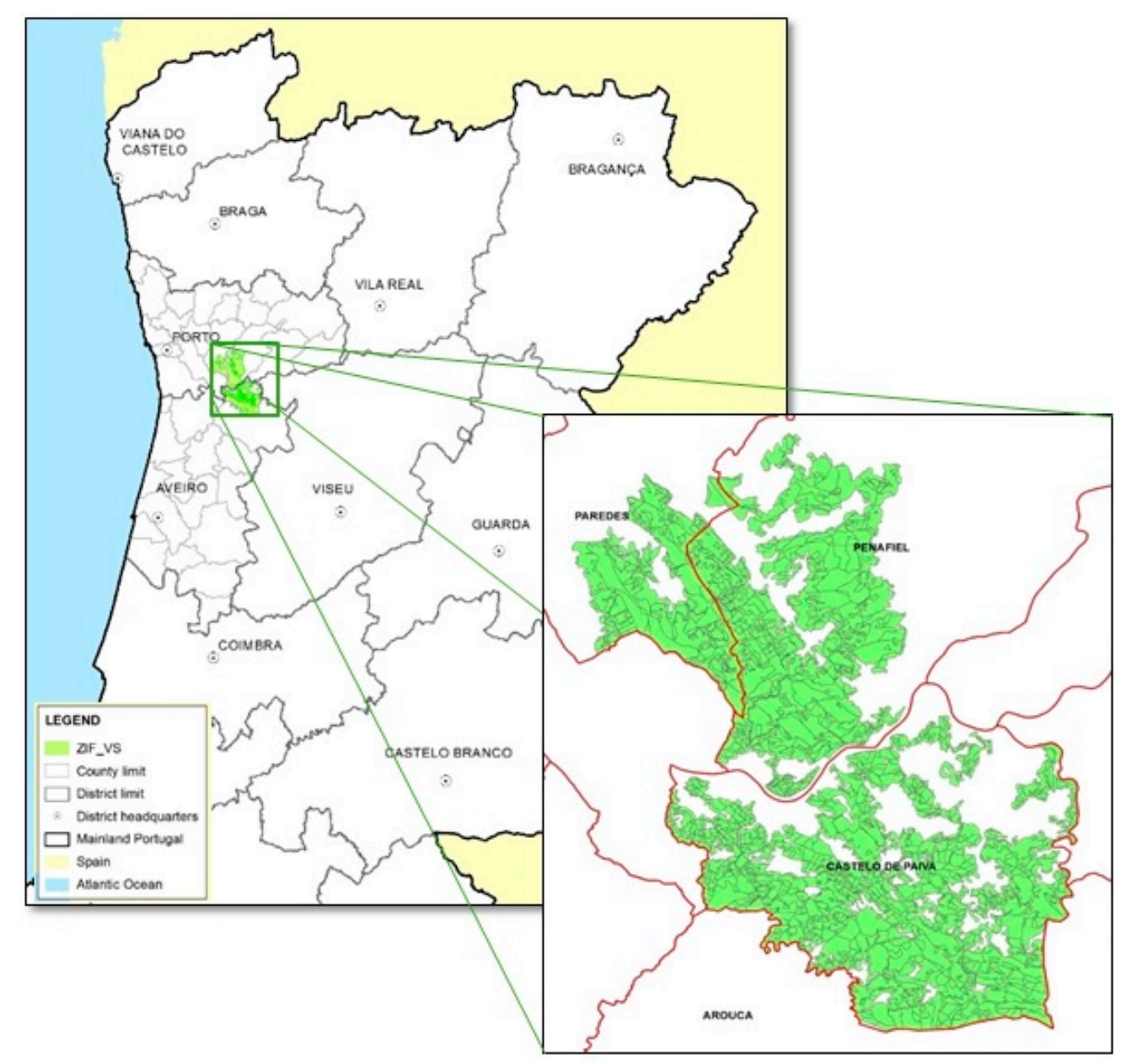

Figure 1. Location of Zona de Intervenção Florestal (ZIF) Vale do Sousa (ZIF_VS).

\subsection{Model Building}

The SADfLOR decision support toolbox [6,61-64] was used to automate the process of model building for the analysis of trade-offs between wildfire criteria and the provision of other ecosystem services. The SADfLOR management information module stored both alphanumeric and 
topological data from ZIF_VS. The prescription writer and simulation modules were used to generate ZIF_VS resource capability models (RCM) [65]. The RCMs are defined by the decision variables, i.e., prescriptions, and their corresponding contributions to the provision of each of the management planning criteria [65].

A total of 430,110 stand-level prescriptions-about 200 prescriptions per stand-were simulated over the 90-year planning horizon with ten 10-year periods. The maritime pine prescriptions assumed plantations with 1400 plants per hectare and rotations of 40, 45, 50, 55 or 60 years, with thinnings occurring every five years between 20 and 50 years of age (up to 5 years before the final harvest) based on a Wilson factor (FW) of 0.27 . The eucalypt prescriptions were plantations of 1400 trees per ha with rotations based on three coppice cycles ranging from 10 to 14 years in length. A stool thinning option was included that leaves an average of two shoots per stool at year 2 of each cycle. Chestnut prescriptions assumed plantations of 1250 trees per ha and alternative thinning periodicities of 5 or 10 years starting at age 15 . Rotations range from 40 to 70 years. Pine, eucalypt and chestnut prescriptions also include alternative fuel treatments periodicities of 1, 5, 10 or 15 years as well as a no fuel treatment option. Additional prescriptions were included to simulate conversion of pine stands to chestnut stands. Growth was projected using PINASTER in the case of even-aged maritime pine stands [66,67], PBirrol in the case of uneven-aged maritime pine stands [68], Globulus 3.0 in the case of even-aged eucalypt stands [69], and GYMMA in the case of uneven-aged eucalypt stands [70]. These models were called by a simulation module, StandSIM/MD [71]. Growth was projected with CASTANEA in the case of chestnut stands [72]. Shrub fuel accumulation was projected according to [52]. At the inventory date, the most common shrubs species were Erica spp. or Calluna spp., Cistus ladanifer, Ulex spp., Adenocarpus argyrophyllus, Rubus fruticosus and Quercus lusitanica.

Stand-level prescriptions were classified into forest management programs to help keep track of the distribution of forest area assigned to each program: Program 1-mixed maritime pine and eucalypt with dominance of maritime pine; Program 2-mixed eucalypt and maritime pine with dominance of eucalypt; Program 3-sweet chestnut, and Program 4-pure eucalypt plantations. The impact of prescriptions on the wildfire criteria was quantified according to four alternative indicators [51].

The management planning RCM may thus be described as:

$$
\begin{aligned}
& \sum_{j=1}^{M_{i}} x_{i j}=a_{i} \mathrm{i}=1, \ldots, N \\
& \sum_{j=1}^{M_{i}} x_{i j}=a_{i} \mathrm{i}=1, \ldots, N \\
& \sum_{i=1}^{N} \sum_{j=1}^{M i} \text { eucalyptw }_{i j t} x_{i j}=\text { Eucalypt }_{t} \quad t=1, \ldots, T \\
& \sum_{i=1}^{N} \sum_{j=1}^{M i} \text { chestnutw }_{i j t} x_{i j}=\text { ChestnutW }_{t} \quad t=1, \ldots, T \\
& \sum_{i=1}^{N} \sum_{j=1}^{M i} \operatorname{carb}_{i j t} x_{i j}=\operatorname{Carb}_{t} \quad t=1, \ldots, T \\
& \sum_{i=1}^{N} \sum_{j=1}^{M i} n p v_{i j} x_{i j}=N P V \\
& \sum_{i=1}^{N} \sum_{j=1}^{M i} c s_{i j} x_{i j}=C \\
& \sum_{t=1}^{T} \text { PineW }_{t}=\text { PineSawlogs } \\
& \sum_{t=1}^{T} \text { Eucalypt } W_{t}=\text { EucalyptPulpwood } \\
& \sum_{t=1}^{T} \text { Chestnut } W_{t}=\text { ChestnutSawlogs } \\
& \sum_{t=1}^{T} \frac{\operatorname{Carb}_{t}}{T}=C A R B \\
& \sum_{i=1}^{N} \sum_{j=1}^{M i} v e i_{i j} x_{i j}=V E I
\end{aligned}
$$




$$
\begin{gathered}
\sum_{i=1}^{N} \sum_{j \in F M P_{i f}} x_{i j}=A_{F M P_{f}} f=1, \ldots, 4 \\
\sum_{j=1}^{M_{i}} \frac{r_{i j t} x_{i j}}{a_{i}}=R_{i t} \quad i=1, \ldots, \mathrm{N}, t=1, \ldots, T \\
\sum_{i=1}^{N} \frac{a_{i} R_{i t}}{F A}=W F_{T} \quad t=1, \ldots, T \\
\sum_{t=1}^{T} \frac{W F_{T}}{T}=W F \\
\sum_{t=1}^{T} \frac{W F_{T}}{T}=W F \\
\sum_{i=1}^{N} \frac{a_{i} R a_{i t}}{F A}=W F a_{t} t=1, \ldots, T \\
\sum_{t=1}^{T} \frac{W F a_{t}}{T}=W F a \\
x_{i j} \geq 0, \forall i, j
\end{gathered}
$$

where:

$N$ is the number of stands;

$M_{i}$ is the number of prescriptions for stand $i$;

$T$ is the number of planning periods;

$x_{i j}$ is the number of ha of stand $i$ assigned to prescription $j$;

$a_{i}$ is the total area (hectares) of stand $i$;

$F A$ is the total forested area (hectares) in the ZIF_VS;

pinew $_{i j t}$ is the pine sawlog volume $\left(\mathrm{m}^{3}\right)$ per hectare in period $t$ that results from assigning one hectare of stand $i$ to prescription $j$;

Pine $_{t}$ is the pine sawlog volume $\left(\mathrm{m}^{3}\right)$ produced in period $t$;

PineSawlogs is the total volume of pine sawlogs $\left(\mathrm{m}^{3}\right)$ produced during the planning horizon;

eucalypt $w_{i j t}$ is the eucalypt pulpwood volume $\left(\mathrm{m}^{3}\right)$ per hectare in period $t$ that results from assigning one hectare of stand $i$ to prescription $j$;

Eucalypt $W_{t}$ is the eucalypt pulpwood volume $\left(\mathrm{m}^{3}\right)$ produced in period $t$;

EucalyptPulpwood is the total volume of eucalypt pulpwood $\mathrm{m}^{3}$ ) produced during the planning horizon; chestnutw $w_{i j t}$ is the chestnut sawlog volume $\left(\mathrm{m}^{3}\right)$ per hectare in period $t$ that results from assigning one hectare of stand $i$ to prescription $j$;

Chestnut $W_{t}$ is the chestnut sawlog volume $\left(\mathrm{m}^{3}\right)$ produced in period $t$;

ChestnutSawlogs is the chestnut sawlog volume $\left(\mathrm{m}^{3}\right)$ produced during the planning horizon;

$\operatorname{carb}_{i j t}$ is average yearly carbon stock (tonnes) per hectare in period $t$ that results from assigning one hectare of stand $i$ to prescription $j$;

Carb $_{t}$ is average yearly carbon stock (tonnes) for the forest as a whole in period $t$;

$C A R B$ is average yearly carbon stock (tonnes) for the forest as a whole over the planning horizon; $n p v_{i j}$ is net present value $(€)$ per hectare produced by prescription $j$ in stand $i$;

$N P V_{j}$ is net present value $(€)$ of the plan for the forest as a whole;

$c s_{i j}$ is the discounted cost of fuel treatments $(€)$ per hectare for prescription $j$ in stand $i$;

$C$ is the total discounted cost of fuel treatments $(€)$;

$v e i_{i j}$ is the standing volume of ending inventory $\left(\mathrm{m}^{3}\right)$ per hectare in stand $i$ under prescription $j$;

$V E I$ is the standing volume of ending inventory $\left(\mathrm{m}^{3}\right)$ for the forest as a whole;

$F$ is the number of forest management programs;

$F M P_{\text {if }}$ is the set of prescriptions for stand $i$ that were classified as belonging to forest management $\operatorname{program} f$; 
$A_{F M P_{f}}$ is the area assigned to forest management program $f$ (hectares);

$r_{i j t}$ is the expected percentage of surviving trees in stand $i$ in period $t$ under prescription $j$;

$R_{i t}$ is the specific wildfire resistance of stand $i$ in period $t$, with $R_{i t} \in[0,1]$;

$W F_{t}$ is the average specific wildfire resistance of the forested landscape in period $t$, with $W F_{t} \in[0,1]$;

$W F$ is the average specific wildfire resistance of the forested landscape over the planning horizon, with $W F \in[0,1]$

$R_{s t}$ is the adjusted wildfire resistance of stand $s$ neighbor of stand $i$ in period $\mathrm{t}$, with $R_{s t} \in[0,1]$;

$\vartheta_{\{i\}}$ is the set of neighbors of stand $i$;

$R a_{i t}$ is the adjusted wildfire resistance of stand $i$ in period $t$, with $R a_{i t} \in[0,1] ; R a_{i t}$ incorporates the wildfire resistance levels of adjacent stands and the risk of fire spread;

$\left(1-w_{i}\right)$ is a weight that reflects the impact of neighboring stands on the wildfire resistance of stand $i$; $\left(1-w_{i}\right) \in[0,1] ; w_{i}$ depends on parameters that reflect the size and shape of the stand $i$; we assume $w_{i}>0$;

$\alpha_{i s}$ is a parameter that reflects the likelihood that a fire that occurs in stand $s$ will spread to stand $i$; $0 \leq \alpha_{i s} \leq 1$ and $\sum_{s \in \vartheta\{i\}} \alpha_{i s} \leq 1 . \theta_{\{i\}}$ [52].

$W F a_{t}$ is the forested landscape adjusted specific resistance in period $t$, with $W F a_{t} \in[0,1]$;

$W F a$ is the average adjusted specific resistance of the forested landscape over the planning horizon, with $W F a \in[0,1]$.

Equation set (1) states that the sum of the areas assigned to each prescription from a stand cannot exceed the area of the stand $\left(a_{i}\right)$. Equation sets (2-4) determine, respectively, the pine, eucalypt and chestnut timber volume produced in each period. Equation set (5) determines the average carbon stock in each planning period. Equation sets (6-12) define, respectively, the net present value, the total costs of fuel treatments, the total pine sawlog production, the total eucalypt pulpwood production, the total chestnut sawlog production, the average carbon stock across planning periods, and the value of the inventory in the study area at the end of the planning horizon. These equations thus define the values of the ecosystem services criteria considered for testing purposes in the study area. Equation set (13) defines the area assigned to each forest management program. Equation set (14) computes the stand-i-specific wildfire resistance indicator in period $t$. This is a weighted average of the expected percentage of surviving trees in stand $i$, in period $t\left(r_{i j t}\right)$, where the weights represent the area of the stand assigned to each prescription $j$. The computation of $r_{i j t}$ assumes independence of wildfire occurrence in the years in the period; i.e., it assumes that a wildfire may occur consecutively every year in the period. The proportion of surviving trees, in each year of a period $t$, builds from the number of live trees in the previous year according to wildfire occurrence and post-fire mortality probability models [53,54].

Equation set (15) computes the forested landscape wildfire resistance in period $t\left(W F_{t}\right)$ as a weighted average of each stand's specific resistances, where the weights correspond to the stand areas. Equation set (16) computes the average wildfire resistance of the forested landscape over the planning horizon (WF). Equation set (17) computes the stand $i$ adjusted wildfire resistance in period $t$. Equation set (18) computes the forested landscape adjusted resistance in period $t\left(W F a_{t}\right)$ as a weighted average of each stand's adjusted resistances, where the weights correspond to the stand areas. Equation set (19) computes the average adjusted resistance of the forested landscape over the planning horizon $(W F a)$. Equation set (20) states the non-negativity constraints.

A Pareto frontier MCDM module [5,59] was used to generate the feasible set in the criteria space for the forest ecosystem management problem as well as to produce and display the information about the trade-offs among the management planning criteria: net present value, pine sawlogs, eucalyptus pulpwood, chestnut sawlogs, average carbon storage, volume of the ending inventory, fuel treatment costs, area of each forest management program, and wildfire risk according to the four indicators (WF, WFa, $W F_{T}$ and $W F a_{T}$; Equations (15), (16), (18) and (19)). 


\section{Results}

The SADfLOR Pareto Frontier module solved a large number of instances of the model described in Equations (1)-(20) to provide information about the trade-offs among the management planning criteria in the form of decision maps. Each decision map is based on a set of solutions in a two-criteria space (Figure 2). Results demonstrate that fuel treatments substantially impact the wildfire resistance criteria (Figure 2). The decision maps display all feasible combinations of fuel treatment costs and wildfire resistance. They show the trade-offs between those costs and the four wildfire resistance indicators-WF, $\mathrm{WF}_{\mathrm{T}}$, WFa and $\mathrm{WFa}_{\mathrm{T}}$ (Figure $2 \mathrm{a}-\mathrm{d}$, respectively)-within the ZIF_VS. These results confirm that increasing investments in fuel treatments can produce higher wildfire resistance.

The non-adjusted wildfire resistance indicators $\left(\mathrm{WF}\right.$ and $\mathrm{WF}_{\mathrm{T}}$ ) range from 0.525 to 0.813 and from 0.512 to 0.801 , respectively, while the corresponding fuel treatment costs range from $€ 0$ to $€ 290.09 \times 10^{5}$ and $€ 0$ to $€ 275 \times 10^{5}$ (Figure $2 \mathrm{a}, \mathrm{b}$ ). In the case of the adjusted indicators (WFa and $\mathrm{WFa}$ ), the ranges extend from 0.514 to 0.801 and from 0.502 to 0.794 , respectively, while the corresponding fuel treatment costs range from $€ 0$ to $€ 257.72 \times 10^{5}$ and $€ 255.62 \times 10^{5}$ (Figure $2 \mathrm{c}, \mathrm{d}$ ). The values of the non-adjusted resistance are greater than the values of adjusted resistance for the same value of fuel treatment costs, highlighting the importance of landscape-level considerations when addressing wildfire risk, namely the impact of the stand neighborhood context on stand-level wildfire resistance. The maximum values of adjusted indicators are lower than the maximum values of non-adjusted indicators, and they are associated with lower fuel treatment costs, suggesting that the periodicity of fuel treatments should not be the only factor to consider when designing wildfire prevention strategies. The impact of the neighborhood context on wildfire resistance suggests the importance of the spatial distribution of fuel treatments. The maximum value of the indicators that reflect the conditions at the end of the planning horizon are lower than the maximum value of indicators of average wildfire resistance over the planning horizon. The former are associated with lower fuel treatment costs. This may be a consequence of the initial inventory and of how fuel treatements were incorporated in the stand-level prescriptions, i.e., with a fixed periodicity.

The information provided by the decision maps shows the investment in fuel treatments that is needed to increase the landscape wildfire resistance by specific amounts. Moreover, it provides information about the marginal cost associated with increasing that resistance. For example, the decision maps show that an increase of WF from 0.7 to 0.8 requires an investment in fuel treatments of approximately $€ 18 \times 10^{6}$ (from $€ 2.33 \times 10^{6}$ to $€ 20.6 \times 10^{6}$ ) (Figure 2a). The marginal cost associated with further increases of WF are much higher, as highlighted by the sharp change in the slope of the Pareto frontier in the decision map (Figure 2a). This pattern is also observed in the case of the other three wildfire resistance indices.

The trade-offs between the wildfire resistance indicators and the standing volume of the ending inventory can also be assessed. Higher ending inventory volumes lead to lower resistance as measured by both adjusted and non-adjusted wildfire resistance at the end of the planning horizon (Figure 3a,b, respectively). The non-adjusted and the adjusted indicators' minimum values are 0.631 and 0.619 , respectively, again reflecting the importance of the spatial context of stands for a more accurate assessment of the landscape resistance to wildfires. The decision maps highlight further that the marginal impact on wildfire resistance of decreasing the level of the inventory at the end of the planning horizon $\left(\mathrm{m}^{3}\right)$ is much higher for levels above $2.05 \times 10^{6} \mathrm{~m}^{3}$. This suggests that to further increase the landscape wildfire resistance, the forest manager should consider the spatial distribution of the inventory rather than just its volume.

The average carbon stock is an important ecosystem service from this landscape [55]. Thus, we used our approach to evaluate trade-offs between the carbon stock and wildfire resistance using our four indicators (Figure 4). The average amount of carbon stored in the forest over the 90 years of the planning horizon ranges from $515 \times 10^{3}$ to $613 \times 10^{3} \mathrm{Mg} /$ year/hectare (Figure $4 \mathrm{a}, \mathrm{c}$ ), according to the set of prescriptions used to model the landscape, while that stock in the last planning period may reach a minimum of approximately $457 \times 10^{3} \mathrm{Mg} /$ year/hectare (Figure $4 \mathrm{~b}, \mathrm{~d}$ ). 
All four decision maps indicate that wildfire resistance increases with decreases in the carbon stock. Furthermore, the marginal impact of the decrease of the carbon stock is higher for values above $600 \times 10^{3} \mathrm{Mg} /$ year/hectare. This result is consistent with the trade-offs between wildfire resistance and the volume of the ending inventory.
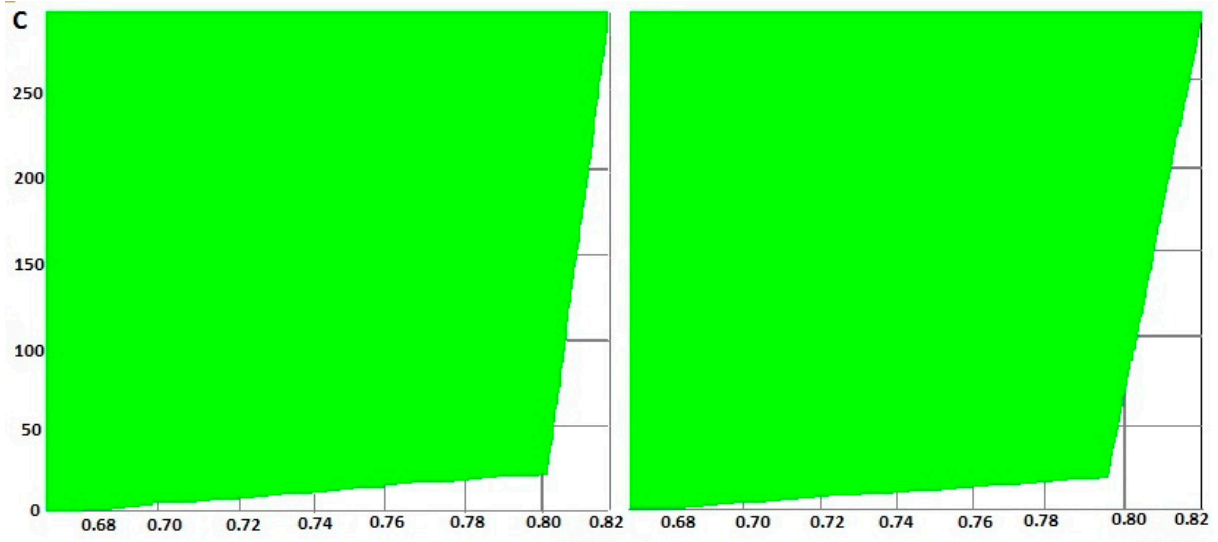

a)

b)
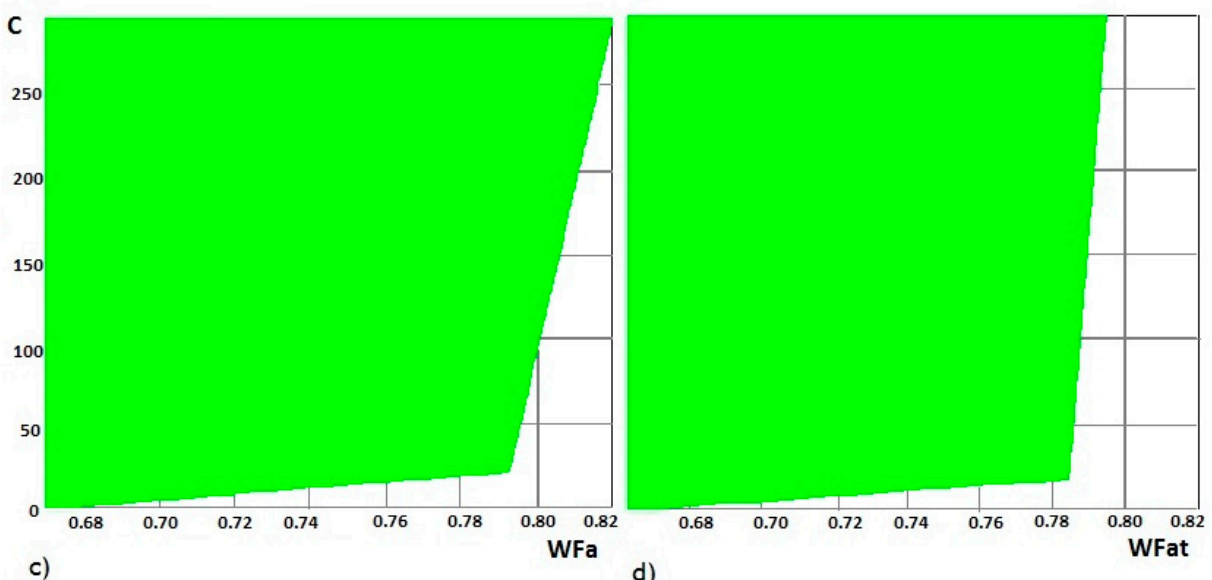

c)

d)

Figure 2. Trade-offs between fuel treatment costs (C) and (a) the non-adjusted average resistance wildfire indicator (WF); (b) the non-adjusted resistance wildfire indicator at the end of the planning horizon (WFT); (c) the non-adjusted average resistance wildfire indicator (WFa); and (d) the non-adjusted resistance wildfire indicator at the end of the planning horizon (WFaT).

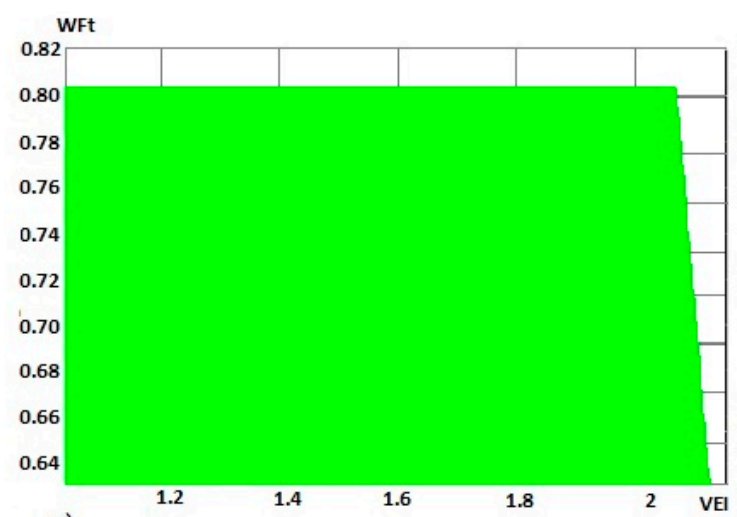

a)

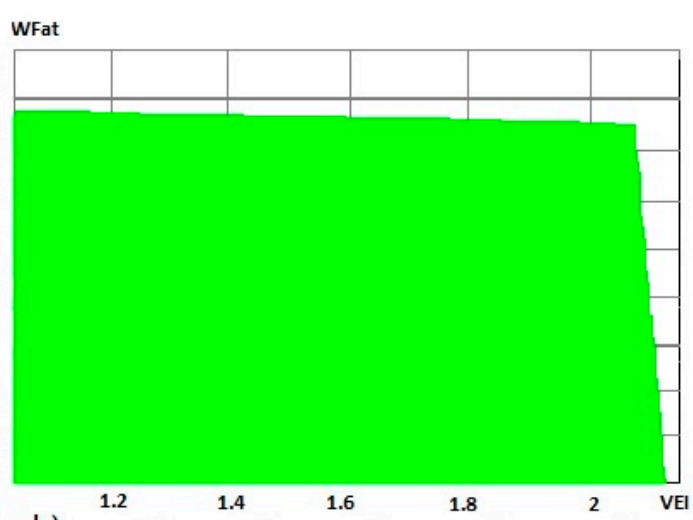

b)

Figure 3. Trade-offs between the volume of the ending inventory (VEI) and the wildfire resistance indices at the end of planning horizon (a) $\mathrm{WF}_{\mathrm{T}}$ and (b) $\mathrm{WFa}_{\mathrm{T}}$. 

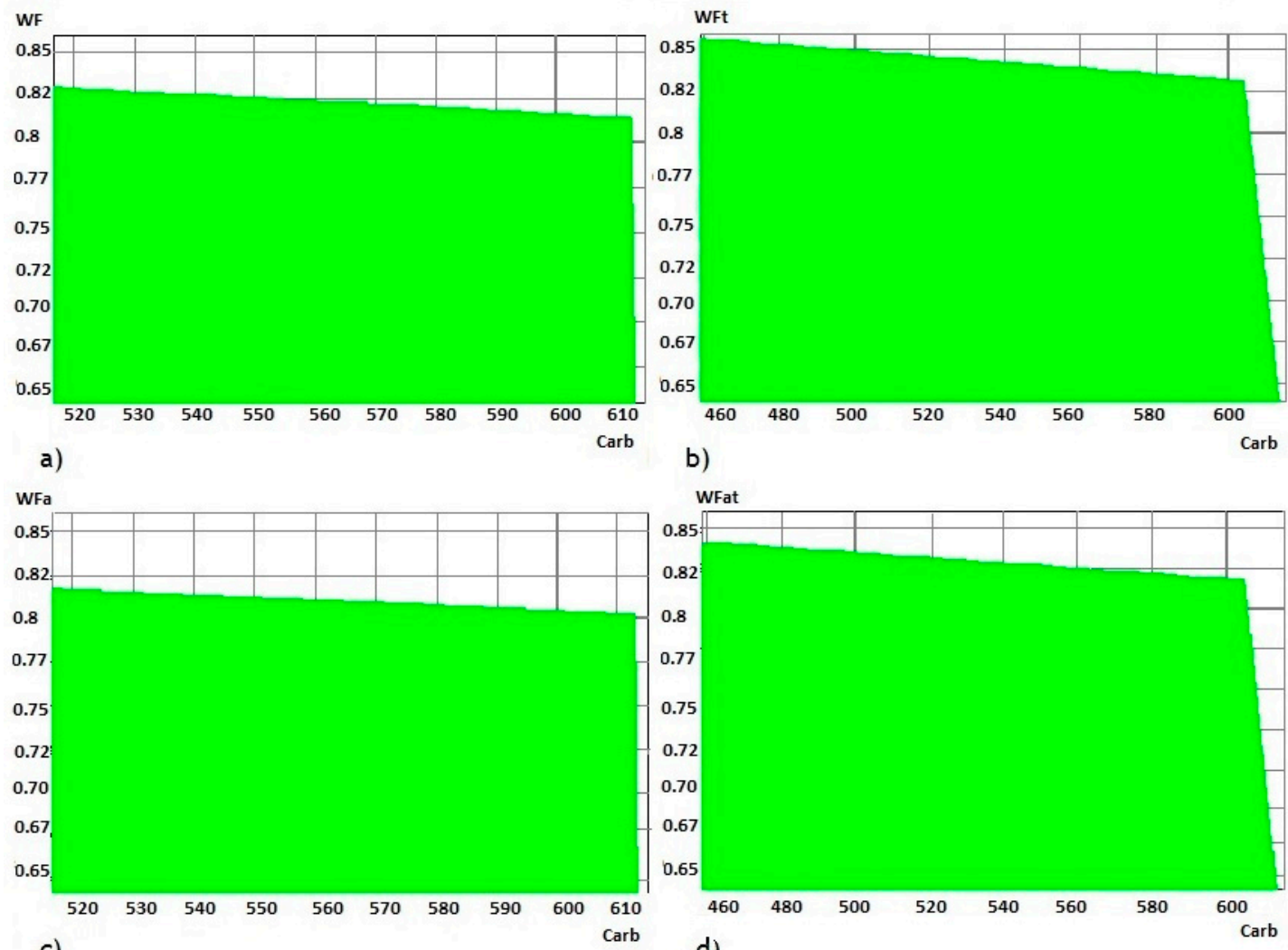

b)

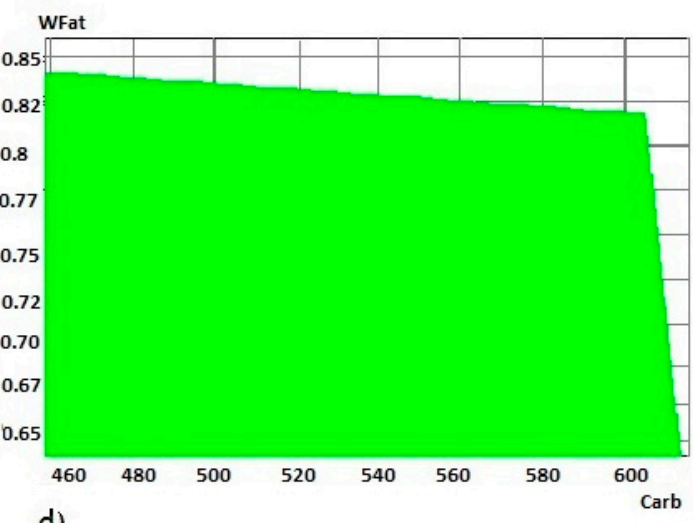

d)

Figure 4. Trade-offs between the average carbon stock over the planning horizon and the average carbon stock in the last planning period and the wildfire resistance indicators (a) WF; (b) $\mathrm{WF}_{\mathrm{T}}$; (c) $\mathrm{WFa}$; and (d) $\mathrm{WFa}_{\mathrm{T}}$, respectively.

We also used our approach to assess the trade-offs between wildfire resistance as measured by WF and the provision of timber and the volume of the ending inventory (Figure 5). The total volume of wood harvested from the forest over the 90-year planning horizon may range from $14.6 \times 10^{6}$ to $16.2 \times 10^{6} \mathrm{~m}^{3}$. The wildfire resistance indicators decrease with the volume harvested, from 0.80 to 0.66 . This result is consistent with the trade-offs between wildfire resistance and ending inventory volume, as the ending inventory decreases with the volume harvested over the planning horizon.

We further analyzed the trade-offs between the volume harvested, the average carbon storage, the standing volume in the ending inventory, and the wildfire resistance as measured by WF. The display of the trade-offs between these four criteria may help forest managers select the targets to be considered when developing a forest management plan. As an illustration, we assume that managers select 0.76 (Figure 6) as the wildfire resistance target value. The set of decision maps associated with this target may be used for a more detailed analysis of targets for the remaining three criteria (Figure 7).

We assume further that the decision-makers select the value $1.5 \times 10^{6} \mathrm{~m}^{3}$ as the target for the standing volume in the ending inventory. The corresponding decision map (Figure 7) provides information about the trade-offs between the total timber harvested and the average carbon stock for the target levels set for the wildfire resistance and the standing volume in the ending inventory. The decision-makers may select a solution along the Pareto frontier associated to this decision map (Figure 7): for example, a solution that provides a total volume harvested of $\approx 15.48 \times 10^{6} \mathrm{~m}^{3}$ and an average carbon storage of $\approx 593.47 \times 10^{3} \mathrm{Mg}$ (Table 1 ). 


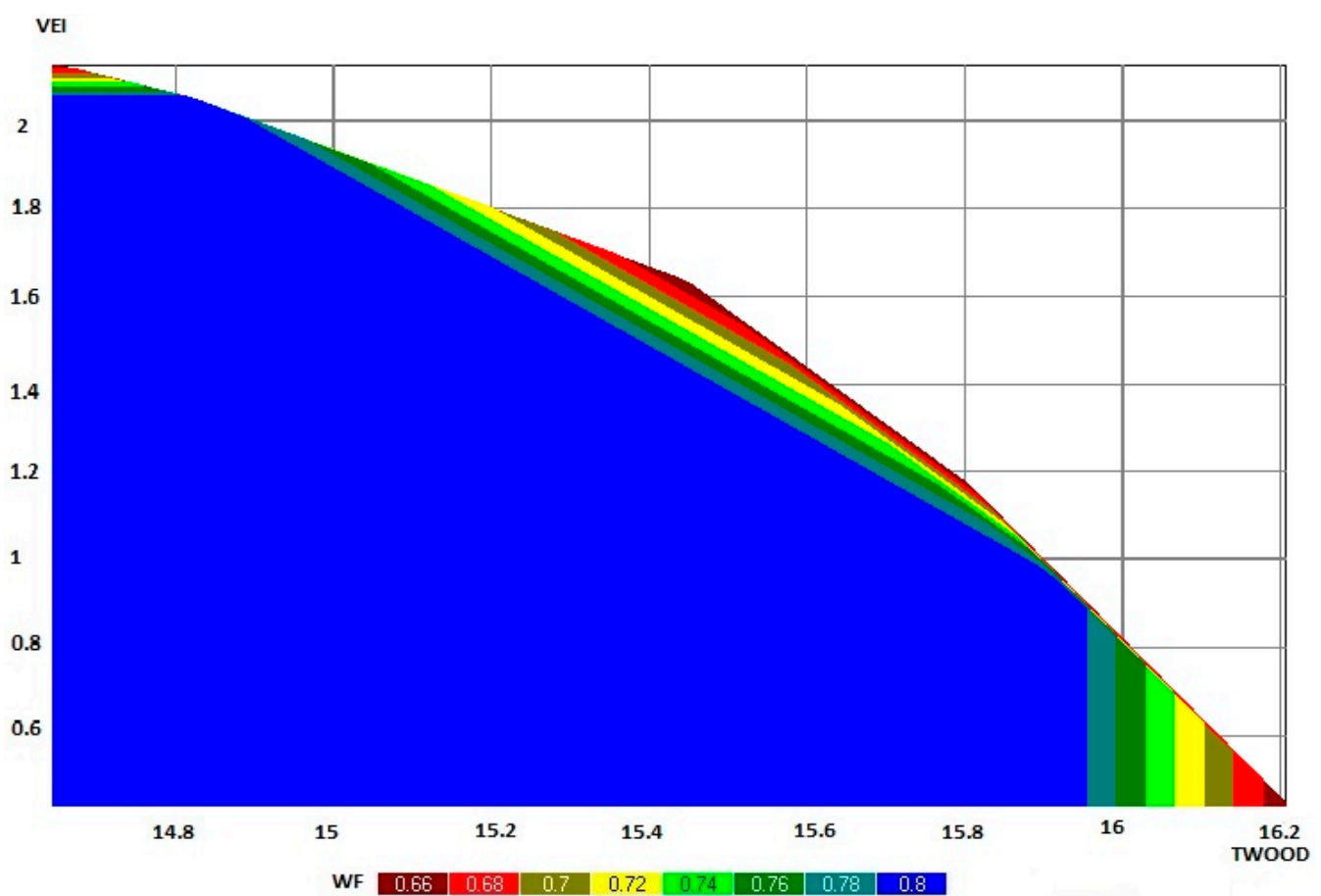

Figure 5. Trade-offs between ecosystem services where VolEI = volume of the ending inventory, $\mathrm{WF}=$ landscape wildfire resistance, TWood = total harvested wood (pine saw logs + eucalypt pulpwood + chestnut saw logs). Each decision map displays the different levels of WF ranging from 0.66 to 0.8 and shows the trade-offs between TWood and VolEI for a specific level of WF. A set of maps is selected for further analysis.

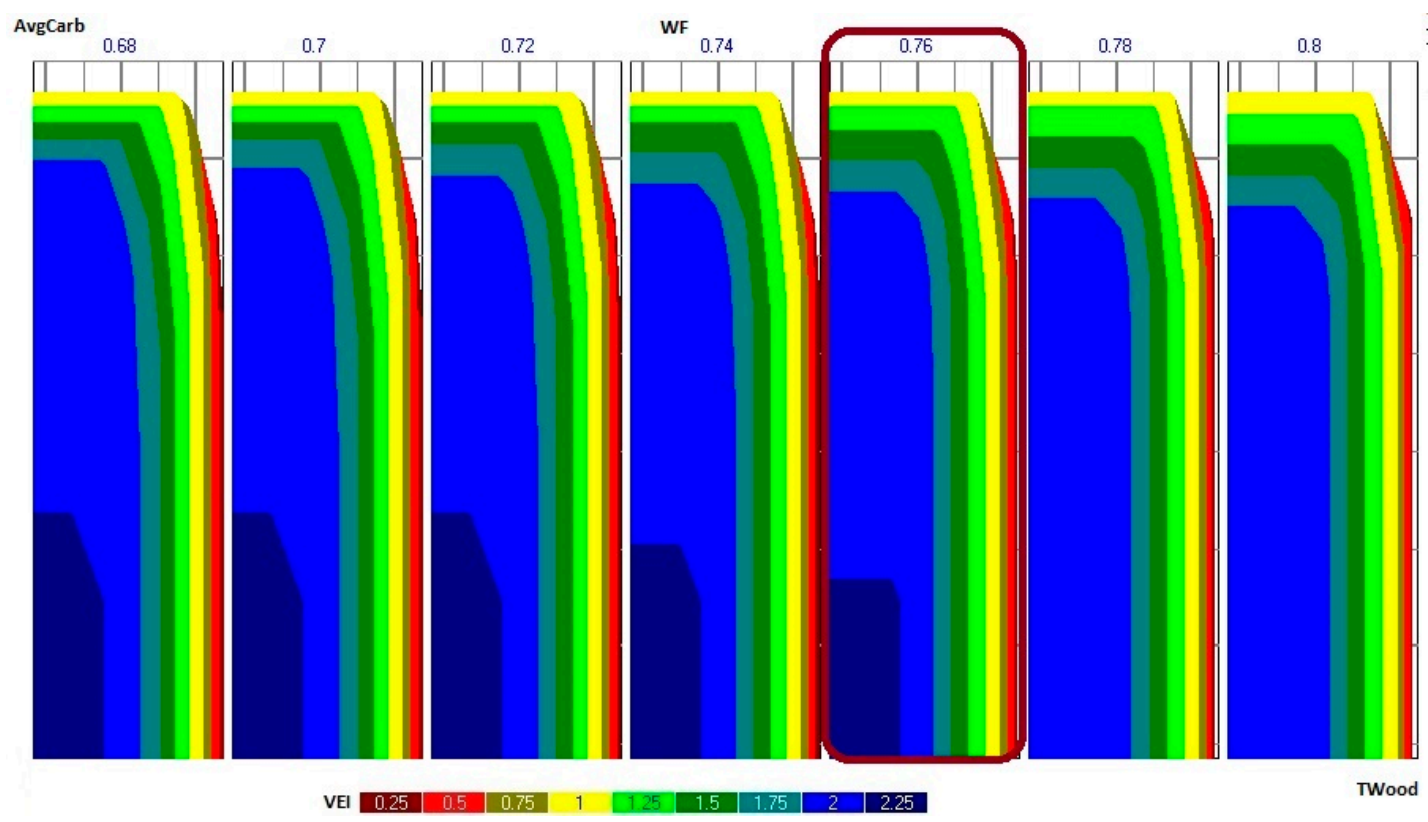

Figure 6. Trade-offs between ecosystem services where VolE = volume of the ending inventory, $\mathrm{WF}=$ Landscape wildfire resistance, $\mathrm{TWood}=$ total harvested wood (pine saw logs + eucalypt pulpwood + chestnut saw logs) and AvgCar = average carbon storage. Each subchart displays the set of decision maps for a level of WF, which ranges from 0.68 to 0.8 . Each set of up to eight decision maps displays the different levels of VolEI ranging from 0.25 to 2.25. Each decision map displays the trade-offs between TWood and AvgCar for a specific level of VolEI. 


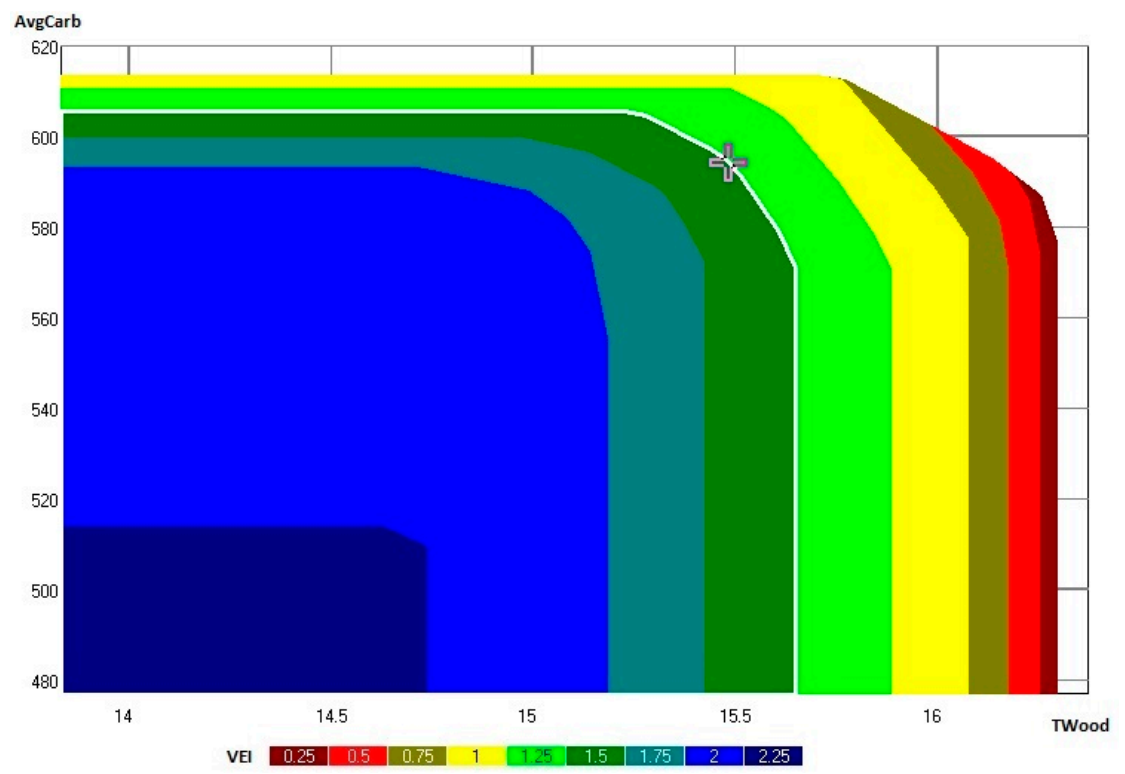

Figure 7. Set of decision maps with WF equal to 0.76 (TWood = total harvested wood (pine saw logs + eucalypt pulpwood + chestnut saw logs), AvgCar = average carbon storage and VolEI = volume of the ending inventory). Each of the nine decision maps corresponds to a level of supply of VolEI, which ranges from $0.25 \times 10^{6}$ to $2.25 \times 10^{6} \mathrm{~m}^{3}$. Each decision map displays the trade-offs between the provision of TWood and AvgCar for each level of supply of VolEI. The white line indicates the selected Pareto frontier and the plus sign indicates the selected point.

Table 1. Ecosystem services supply for the selected point in the decision map (represented by the plus sign). The selected point represents the level of each ecosystem service.

\begin{tabular}{ccc}
\hline Ecosystem Service List & Value & Units \\
\hline HV_Euc & 14.72 & $10^{6} \mathrm{~m}^{3}$ \\
HV_Mp & 0.23 & $10^{6} \mathrm{~m}^{3}$ \\
HV_Chest & 0.14 & $10^{6} \mathrm{~m}^{3}$ \\
Thwood & 0.39 & $10^{6} \mathrm{~m}^{3}$ \\
TWood & 15.48 & $10^{6} \mathrm{~m}^{3}$ \\
AvgCarb & 593.47 & $10^{3} \mathrm{Mg} \cdot \mathrm{year}^{-1}$ \\
VolEI & 1.5 & $10^{6} \mathrm{~m}^{3}$ \\
Euc area & 12729.9 & $\mathrm{Ha}$ \\
MP area & 1174.5 & $\mathrm{Ha}$ \\
Chestnut area & 256.9 & $\mathrm{Ha}$ \\
AreaConvMPChest & 355.39 & $\mathrm{Ha}$ \\
WF & 0.760 & - \\
WF & 0.747 & - \\
Wfa & 0.742 & - \\
WFa & 0.731 & - \\
FTCosts & 145.41 & $€ 10^{4}$
\end{tabular}

Where: HV_Euc $=$ eucalypt volume harvested, HV_Mp = maritime pine volume harvested; HV_Chest $=$ chestnut volume harvested; Thwood = thinned wood from maritime pine, eucalyptus and chestnuts; TWood = total volume harvested + thinned; AvgCarb = average carbon stock per year; VolEI = volume of ending inventory; Euc area = area occupied with eucalypt; MParea $=$ area occupied with maritime pine; Chest area $=$ area occupied with chestnuts; $\mathrm{WF}=$ landscape non-adjusted average wildfire resistance; $\mathrm{WF}_{\mathrm{T}}=$ landscape non-adjusted wildfire resistance at the end of the planning horizon; $\mathrm{WFa}=$ landscape adjusted average wildfire resistance; $\mathrm{WFa}_{\mathrm{T}}=$ landscape adjusted wildfire resistance at the end of the planning horizon; FTCosts-total costs of fuel treatments.

\section{Discussion}

The approach presented here addresses wildfire resistance in a strategic forest management planning model that uses indicators that take into account variables that forest managers are able to 
control (e.g., biometric variables) to estimate the wildfire resistance [51]. González et al. (2005) [73] discussed the potential of using fire resistance indices that reflect stand characteristics that can be controlled by managers to optimize the spatial distribution of forest fuels and fire hazards in Catalonia, Spain. Other researchers $[13,22,23,54,74-76]$ have also used stand-level biometric variables such as basal area and number of trees to develop wildfire risk models and indicators. Chuvieco et al. (2010) [41] considered further the understory fuel load in their index. Our approach demonstrates the potential of the information provided by those models and further considers information about each stand's neighborhood context $[28,29,51,76,77]$. The approach integrates information about wildfire occurrence and damage probabilities as well as about the impact of surrounding conditions on fire as suggested by other authors, e.g., [51,78,79]. Another innovation of the approach is that it addresses trade-offs between wildfire resistance, fuel treatment costs, and the provision of other ecosystem services.

Our results show that wildfire resistance decreases with an increase in the shrub biomass load. This result is consistent with several authors [22-24,51,54] who claim that annual probability of wildfire occurrence and damage increases with the shrub biomass load. The forest cover type, the fuel load (e.g., biomass of shrubs), and the presence of multiple layers with vertical continuity of living fuels such as in young stands have a substantial impact on the probability of wildfire occurrence [80]. Other studies also show that the fire occurrence probability and severity increases as the shrub layer becomes more conspicuous, substantially dryer and more flammable due to higher temperatures [81-83]. Thus, our results are also consistent with the claim by these authors that fire resistance decreases with fuel load because higher fuel load increases fire intensity, which in turn increases the height of canopy scorch and the probability of crown fire. Several management options have been found to reduce wildfire propagation (e.g., thinning, pruning, residue removal, shrub cleanings) $[43,84-86]$. In order to assess wildfire resistance, forest managers need information about the impact of "controllable" variables such as stand density, species composition, fuel availability at surface level (e.g., shrubs) and vertical structure of the stand on the probability of fire occurrence as well as on its severity $[19,80,87,88]$.

Litter fuels are also a big concern in our forests since they account for an important and potentially fast growing contributor to fuel hazard. These components include the litter and duff layers, dead and down woody material, grasses and forbs, shrubs, regeneration and timber. In 1982, Anderson [89] verified that fuel load and depth are significant fuel properties for predicting whether a fire will ignite, its rate of spread and its intensity. In addition to litter, dead and down stemwood from the open shrub or timber overstory contribute to the fire intensity. Roison et al. 1983 [90] verified that litter reaccumulates to dangerous (from a fire control point of view) weights in 3-6 years, thus severely limiting the period during which prescribed burning provides protection from wildfire. The rapid rate of litter reaccumulation is mostly due to a low rate of litter decomposition relative to rates of litter input, rather than to any fire-induced reduction in the rate of decomposition. More recent studies (e.g., $[10,43,91,92])$, have dealt with how litter affects fire risk and resistance. This suggests the potential for enhancing wildfire resistance indicators by including information about litter fuels.

Our approach further shows how the trade-offs between wildfire resistance and fuel treatment costs may help in the design of effective strategies for reducing the shrub biomass load. In fact, it highlights the possibility of defining the marginal cost of producing wildfire resistance and it suggests that this function may have an inflection point beyond which the gains may be outweighed by the costs. This information will be useful in the design of management options and prescriptions so that fire risk can be integrated in practical forest management planning at the landscape level.

This approach may be further useful in helping stakeholders set targets for wildfire resistance criteria and in providing a clearer representation of the decision-making problem. Nevertheless, it does not require stakeholders to set targets before information is available about the trade-offs between the wildfire resistance criteria and fuel treatment costs as well as the provision of other ecosystem services. Results are in concordance with findings from other authors that report the effectiveness 
of a posteriori preference modeling approaches (e.g., $[1,4,56,93])$ for supporting the negotiation of ecosystem services [60].

\section{Conclusions}

This research demonstrates a modeling approach that can help integrate wildfire risk assessment in forest management planning. Specifically, the approach integrates wildfire resistance indicators in a multiple-criteria decision-making framework that can help decisionmakers define effective wildfire prevention strategies while targeting the supply of other ecosystem services. The indicators considered by this research use stand-level data as well as information about wildfire occurrence and damage. The enhanced wildfire occurrence and damage models should be influential in the development of more accurate indicators. This research supports the potential value of developing species-specific models that are based on variables that can be controlled by forest managers. It further suggests the potential value of including litter fuel control variables.

The indicators used in this research also use information about spatial features of the forest, including stand geometry (e.g., shape and size) and topology (e.g., spatial context) to better address wildfire spread concerns. Additional spatial variables that could be used to enhance indicators for this purpose may be the stands' proximity to roads and to other ignition sources and barriers to spread.

This Pareto frontier, a posteriori multi-criteria decision method can thus be used to support the integration of wildfire risk in multiple-objective forest management planning contexts. Moreover, it can be used to address the trade-offs between resistance to wildfires, fuel treatment strategies, and the supply of other ecosystem services. Extending the range of ecosystem services considered in the management planning process—e.g., to include biodiversity—is feasible within this modeling approach as it may encapsulate spatial optimization approaches. Future research will address the potential to include a wider variety of management objectives. This research has demonstrated the contribution of this Pareto frontier approach to better understanding the ecological and economic relationhips between wildfire and forest managememt planning and thus will contribute to better decisions.

Acknowledgments: This research has received funding from the European Union's Horizon 2020 research and innovation programme (grant agreement No. 676754) (ALTERFOR), Marie Skodowska-Curie Research and Innovation Staff Exchange (RISE) within the H2020 work programme (H2020-MSCA-RISE-2015). (SUFORUN), Forest Research Center Project UID/AGR/00239/2013 as well as the INFORMED project INtegrated research on FOrest Resilience and Management in the mEDiterranean. The authors would like to thank the Portuguese Science Foundation for funding the Post Doc grant of Susete Marques SFRH/BPD/96806/2013 as well the Ph.D. grant from Marco Marto SFRH/BD/108225/2015.

Author Contributions: Susete Marques analyzed the data, designed and applied the modeling approach and led the drafting of the manuscript. Marco Marto and Vladimir Bushenkov developed and programmed modules that encapsulate the modeling approach. Marc McDill reviewed the presentation of the model and edited the manuscript. José G. Borges analyzed the design and application of the modeling approach and contributed to the drafting of the manuscript.

Conflicts of Interest: The authors declare no conflict of interest. The funding sponsors had no role in the design of the study; in the collection, analyses, or interpretation of data; in the writing of the manuscript, and in the decision to publish the results.

\section{References}

1. Tóth, S.F.; McDill, M.E.; Rebain, S. Finding the Efficient Frontier of a Bi-Criteria, Spatially Explicit, Harvest Scheduling Problem. For. Sci. 2006, 52, 93-107.

2. Diaz-Balteiro, L.; Romero, C. Making forestry decisions with multiple criteria. A review and an assessment. For. Ecol. Manag. 2008, 255, 3222-3241. [CrossRef]

3. Belton, V.; Stewart, T.J. Multiple Criteria Decision Analysis-An Integrated Approach; Kluwer Academic Publishers: Dordrecht, The Netherlands, 2002.

4. Tóth, S.F.; McDill, M.E. Finding Efficient Harvest Schedules under Three Conflicting Objectives. For. Sci. 2009, 55, 117-131. 
5. Borges, J.G.; Garcia-Gonzalo, J.; Bushenkov, V.; McDill, M.E.; Marques, S.; Oliveira, M.M. Addressing multicriteria forest management with Pareto frontier methods: An application in Portugal. For. Sci. 2014, 60, 63-72. [CrossRef]

6. Garcia-Gonzalo, J.; Bushenkov, V.; McDill, M.E.; Borges, J. A Decision Support System for Assessing Trade-Offs between Ecosystem Management Goals: An Application in Portugal. Forests 2015, 6, 65-73. [CrossRef]

7. Armstrong, G.W. Sustainability of timber supply considering the risk of wildfire. For. Sci. 2005, 50, 626-639.

8. Calkin, D.E.; Hummel, S.S.; Agee, J.K. Modeling trade-offs between fire threat reduction and late-seral forest structure. Can. J. For. Res. 2005, 35, 2562-2574. [CrossRef]

9. Konoshima, M.; Albers, H.J.; Montgomery, C.A.; Arthur, J.L. Optimal spatial patterns of fuel management and timber harvest with fire risk. Can. J. For. Res. 2010, 40, 95-108. [CrossRef]

10. Konoshima, M.; Montgomery, C.A.; Albers, H.J.; Arthur, J.L. Spatial-endogenous fire risk and efficient fuel management and timber harvest. Land. Econ. 2008, 84, 449-468. [CrossRef]

11. Lampin-Maillet, C.; Long-Fournel, M.; Ganteaume, A.; Jappiot, M.; Ferrier, J.P. Land cover analysis in wildland-urban interfaces according to wildfire risk: A case study in the South of France. For. Ecol. Manag. 2011, 261, 2200-2213. [CrossRef]

12. Catry, F.X.; Rego, F.C.; Bacao, F.L.; Moreira, F. Modeling and mapping wildfire ignition risk in Portugal. Int. J. Wildland Fire 2009, 18, 1-11. [CrossRef]

13. Catry, F.X.; Rego, F.; Moreira, F.; Fernandes, P.M.; Pausas, J.G. Post-fire tree mortality in mixed forests of central Portugal. For. Ecol. Manag. 2010, 260, 1184-1192. [CrossRef]

14. Marques, S.; Borges, J.G.; Garcia-Gonzalo, J.; Moreira, F.; Carreiras, J.M.B.; Oliveira, M.M.; Cantarinha, A.; Botequim, B.; Pereira, J.M.C. Characterization of wildfires in Portugal. Eur. J. For. Res. 2011, 130, 775-784. [CrossRef]

15. Paton, D.; Tedim, F. Enhancing forest fires preparedness in Portugal: Integrating community engagement and risk management. Planet@Risk 2013, 1, 44-52.

16. Bar Massada, A.; Radeloff, V.C.; Steward, S.I.; Hawbaker, T.J. Wildfire risk in the wildland-urban interface: A simulation study in northwestern Wisconsin. For. Ecol. Manag. 2009, 258, 1990-1999. [CrossRef]

17. Hardy, C. Wildland fire hazard and risk, problems, definitions and context. For. Ecol. Manag. 2005, 211, 73-82. [CrossRef]

18. Bachmann, A.; Allgower, B. The need for a consistent wildfire risk terminology. In Crossing the Millennium: Integrating Spatial Technologies and Ecological Principles for a New Age in Fire Management; Neuenschwander, L., Ryan, K., Golberg, G., Eds.; The University of Idaho and the International Association of Wildland Fire: Moscow, Russia, 2000; pp. 67-77.

19. González, J.R.; Palia, M.; Pukkala, T. A fire probability model for forest stands in Catalonia (north-east Spain). Ann. For. Sci. 2006, 63, 1-8. [CrossRef]

20. Jactel, H.; Nicoll, B.C.; Branco, M.; González-Olabarria, J.R.; Grodzki, W.; Långström, B.; Moreira, F.; Netherer, S. The influences of forest stand management on biotic and abiotic risks of damage. Ann For. Sci. 2009, 66, 701. [CrossRef]

21. Jappiot, M.; Gonzalez-Olabarria, J.R.; Lampin-Maillet, C.; Borgniet, L. Assessing Wildfire Risk in Time and Space. In Living with Wildfires: What Science Can Tell Us; A contribution to the Science-Policy Dialogue; European Forest Institute: Barcelona, Spain, 2009; pp. 41-47.

22. Garcia-Gonzalo, J.; Zubizarreta-Gerendiain, A.; Ricardo, A.; Marques, S.; Botequim, B.; Borges, J.G.; Oliveira, M.M.; Tomé, M.; Pereira, J.M.C. Modelling wildfire risk in pure and mixed forest stands in Portugal. Allg. Forst. 2012, 183, 238-248.

23. Marques, S.; Garcia-Gonzalo, J.; Botequim, B.; Ricardo, A.; Borges, J.G.; Tomé, M.; Oliveira, M.M. Assessing wildfire occurrence probability in Pinus pinaster Ait. stands in Portugal. For. Syst. 2012, 21, 111-120. [CrossRef]

24. Botequim, B.; Garcia-Gonzalo, J.; Marques, S.; Ricardo, A.; Borges, J.G.; Tomé, M.; Oliveira, M.M. Developing wildfire risk probability models for Eucalyptus globulus stands in Portugal. iForest 2013, 6, 217-227. [CrossRef]

25. González, J.R.; Pukkala, T. Characterization of forest fires in Catalonia (north-east Spain). Eur. J. For. Res. 2007, 126, 421. [CrossRef] 
26. Ager, A.A.; Vaillant, N.M.; Finney, M.A. A comparison of landscape fuel treatment strategies to mitigate wildland fire risk in the urban interface and preserve old forest structure. For. Ecol. Manag. 2010, 259, 1556-1570. [CrossRef]

27. Finney, M.A.; Seli, R.C.; McHugh, C.W.; Ager, A.A.; Bahro, B.; Agee, J.K. Simulation of Long-Term Landscape-Level Fuel Treatment Effects on Large Wildfires. Int. J. Wildland Fire 2007, 16, 712-727. [CrossRef]

28. González-Olabarria, J.R.; Pukkala, T. Integrating fire risk considerations in landscape-level forest planning. For. Ecol. Manag. 2007, 261, 278-287. [CrossRef]

29. González-Olabarria, J.R.; Rodríguez, F.; Fernández-Landa, A.; Mola-Yudego, B. Mapping fire risk in the Model Forest of Urbión (Spain) based on airborne LiDAR measurements. For. Ecol. Manag. 2012, 282, 149-156.

30. Kaloudis, S.; Tocatlidou, A.; Lorentzos, N.A.; Sideridis, A.B.; Karteris, M. Assessing wildfire destruction danger: A decision support system incorporating uncertainty. Ecol. Model. 2005, 181, 25-38. [CrossRef]

31. Verde, J.C.; Zêzere, J.L. Assessment and validation of wildfire susceptibility and hazard in Portugal. Nat. Hazards Earth Syst. Sci. 2010, 10, 485-497. [CrossRef]

32. Yassemi, S.; Dragícevic, S.; Schimidt, M. Design and implement of an integrated GIS-based cellular automata model to characterize forest fire behavior. Ecol. Model. 2008, 210, 71-84. [CrossRef]

33. Alonzo-Betanzos, A.; Fontanela-Romeo, O.; Guijarro-Berdiñas, B.; Hernández-Pereira, E.; Andrade, M.; Jiménez, E.; Soto, J.; Carballas, T. An intelligent system for forest fire risk prediction and firefighting management in Galicia. Expert Syst. Appl. 2003, 25, 545-554. [CrossRef]

34. Braun, W.; Jones, B.; Lee, J.; Woolford, D.; Wotton, B. Forest fire risk assessment: An illustrative example from Ontario, Canada. J. Prob. Stat. 2010, 26. [CrossRef]

35. Barros, A.M.G.; Pereira, J.M.C. Wildfire selectivity for land cover type: Does size matter? PLoS ONE 2014, 9 , 1-10. [CrossRef] [PubMed]

36. Schimidt, D.; Taylor, A.; Skinner, C. The influence of fuels treatment and landscape arrangement on simulated fire behavior, Southern Cascade rande, California. For. Ecol. Manag. 2008, 255, 3170-3184. [CrossRef]

37. Grishin, A.M.; Filkov, A.I. A deterministic-probabilistic system for predicting forest fire hazard. Fire Saf. J. 2011, 46, 56-62. [CrossRef]

38. Keane, R.E.; Drury, S.A.; Karau, E.C.; Hessburg, P.F.; Reynolds, K.M. A method for mapping fire hazard and risk across multiple scales and its application in fire management. Ecol. Model. 2010, 221, 2-18. [CrossRef]

39. Paz, S.; Carmel, Y.; Jahshan, F.; Shoshany, M. Post fire analysis of pre-fire mapping of fire risk: A recent case study from Mt. Carmel (Israel). For. Ecol. Manag. 2011, 262, 1184-1188. [CrossRef]

40. Chuvieco, E.; Congalton, R. Apllication of remote sensing and geographic information systems to forest fire hazard mapping. Remote Sens. Environ. 1989, 29, 147-159. [CrossRef]

41. Chuvieco, E.; Aguado, I.; Yebra, M.; Nieto, H.; Salas, J.; Martín, M.P.; Vilar, L.; Martínez, J.; Martín, S.; Ibarra, P.; et al. Development of a framework for fire risk assessment using remote sensing and geographic information system technologies. Ecol. Model. 2010, 221, 46-58. [CrossRef]

42. Chuvieco, E.; Aguado, I.; Jurdao, S.; Pettinari, M.L.; Yebra, M.; Salas, J.; Hantson, S.; de la Riva, J.; Ibarra, P.; Rodrigues, M.; et al. Integrating geospatial information into fire risk assessment. Int. J. Wild. Fire 2012, 23, 606-619. [CrossRef]

43. Ager, A.; Valillant, N.; Finney, M. Integrating fire behavior models and geospatial analysis for wildland fire risk assessment and fuel management planning. J. Combust. 2011. [CrossRef]

44. Aretano, R.; Semeraro, T.; Petrosillo, I.; De Marco, A.; Pasimeni, M.R.; Zurlini, G. Mapping ecological vulnerability to fire for effective conservation management of natural protected areas. Ecol. Model. 2015, 295, 163-175. [CrossRef]

45. Bonazountas, M.; Kallidromitou, D.; Kassomenos, P.; Passas, N. A decision support system for managing forest fire casualities. J. Environ. Manag. 2007, 84, 412-418. [CrossRef] [PubMed]

46. Bonazountas, M.; Kallidromitou, D.; Kassomenos, P.; Passas, N. Forest fire risk analysis. Hum. Ecol. Risk Assess. 2005, 11, 617-626. [CrossRef]

47. Sauvagnargues-Lesage, S.; L'Hëritier, B.; Boussardon, T. Implementation of a GIS application for French fire-fighters in the Mediterranean area. Comput. Environ. Urban Syst. 2001, 25, 307-318. [CrossRef]

48. San-Miguel-Ayanz, J.; Barbosa, P.; Schmuck, G.; LibertÒ, G.; Meyer-Roux, J. The European Forest Fire Information System. In Proceedings of the 6th AGILE, Lyon, France, 24-26 April 2003; pp. 27-30. 
49. Jaiswal, R.; Mukherjee, S.; Raju, K.; Saxena, R. Forest fire risk zone mapping from satellite imagery and GIS. Int. J. Appl. Earth Obs. 2002, 4, 1-10. [CrossRef]

50. Carmel, Y.; Paz, S.; Jahashan, F.; Maxim, S. Assessing fire risk using Monte Carlo simulations of fire spread. For. Ecol. Manag. 2009, 257, 370-377. [CrossRef]

51. Ferreira, L.; Constantino, M.F.; Boges, J.G.; Garcia-Gonzalo, J. Addressing wildfire risk in landscape-level scheduling model: An application in Portugal. For. Sci. 2015, 61, 266-277. [CrossRef]

52. Botequim, B.; Zubizarreta-Gerendiain, A.; Garcia-Gonzalo, J.; Silva, A.; Marques, S.; Fernandes, P.; Pereira, J.; Tomé, M. A model of shrub biomass accumulation as a tool to support management of Portuguese forests. iForest 2015, 8, 114-125. [CrossRef]

53. Marques, S.; Garcia-Gonzalo, J.; Borges, J.G.; Botequim, B.; Oliveira, M.M.; Tomé, J.; Tomé, M. Developing post-fire Eucalyptus globulus stand damage and tree mortality models for enhanced forest planning in Portugal. Silva Fenn. 2011, 45, 69-83. [CrossRef]

54. Garcia-Gonzalo, J.; Marques, S.; Borges, J.G.; Botequim, B.; Oliveira, M.M.; Tomé, J.; Tomé, M. A three-step approach to post-fire mortality modeling in Maritime pine (Pinus pinaster Ait.) stands for enhanced forest planning in Portugal. Forestry 2011, 84, 197-206. [CrossRef]

55. Kangas, J.; Kangas, A. Multiple criteria decision support in forest management-The approach, methods applied, and experiences gained. For. Ecol. Manag. 2005, 207, 133-143. [CrossRef]

56. Nordström, E.-M.; Eriksson, L.O.; Öhman, K. Integrating multiple criteria decision analysis in participatory forest planning: Experience from a case study in northern Sweden. For. Pol. Econ. 2010, 12, 562-574. [CrossRef]

57. Korosuo, A.; Wikström, P.; Öhman, K.; Eriksson, L.O. An integrated mcda software application for forest planning: A case study in southwestern Sweden. Math. Comput. For. Nat. Resour. Sci. 2011, 3, 75-86.

58. Kangas, A.; Kangas, J.; Pykäläinen, J. Outranking methods as tools in strategic natural resources planning. Silva Fenn. 2001, 35, 215-227. [CrossRef]

59. Lotov, A.V.; Bushenkov, V.A.; Kamenev, G.K. Interactive Decision Maps: Approximation and Visualization of Pareto Frontier; Kluwer Academic Publishers: Norwell, MA, USA, 2004; p. 319.

60. Borges, J.G.; Marques, S.; Garcia-Gonzalo, J.; Rahman, A.U.; Bushenkov, V.; Sottomayor, M.; Carvalho, P.O.; Nordström, E.M. Negotiating ecosystem services supply targets as well as forest owners behaviors and programs with multiple criteria methods. For. Sci. 2017, 63, 49-61.

61. Borges, J.G.; Falcão, A.; Miragaia, C.; Marques, P.; Marques, M. A decision support system for forest resources management in Portugal. In Managing Forest Ecosystems; Arthaud, G.J., Barrett, T.M., Eds.; Springer: Dordrecht, The Netherlands, 2003; Volume 7, pp. 155-164.

62. Ribeiro, R.P.; Borges, J.G.; Oliveira, V. A framework for data quality for Mediterranean sustainable ecosystem management. Ann. For. Sci. 2004, 61, 557-568. [CrossRef]

63. Falcão, A.; Borges, J.G. Designing decision support tools for Mediterranean forest ecosystems management: A case study in Portugal. Ann. For. Sci. 2005, 62, 751-760. [CrossRef]

64. Garcia-Gonzalo, J.; Palma, J.; Freire, J.; Tomé, M.; Mateus, R.; Rodriguez, L.C.E.; Bushenkov, V.; Borges, J.G. A decision support system for a multi stakeholder's decision process in a Portuguese National Forest. For. Syst. 2013, 22, 359-373. [CrossRef]

65. Davis, L.S.; Johnson, K.N. Forest Management, 3rd ed.; McGraw Hill Publishing Company: New York, NY, USA, 2001.

66. Nunes, L.; Tomé, J.; Tomé, M. Prediction of annual tree growth and survival for thinned and unthinned even-aged maritime pine stands in Portugal from data with different time measurement intervals. For. Ecol. Manag. 2011, 262, 1491-1499. [CrossRef]

67. Nunes, L.; Patrício, M.; Tomé, J.; Tomé, M. Modeling dominant height growth of maritime pine in Portugal using GADA methodology with parameters depending on soil and climate variables. Ann. For. Sci. 2011, 68, 311-323. [CrossRef]

68. Alegria, C.M.M. PBIRROL Modelo de Crescimento e Produção para os Povoamentos de Pinheiro bravo de Estrutura Irregular do Concelho de Oleiros; Instituto Politécnico de Castelo Branco: Castelo Branco, Portugal, 2007; pp. 13-18. (In portuguese)

69. Tomé, M.; Oliveira, T.; Soares, P. O modelo Globulus 3.0. Publicações GIMREF-RC2/2006; Instituto Superior de Agronomia: Lisboa, Portugal, 2006; p. 23. Available online: http://www.repository.utl.pt/handle/10400.5/ 1760 (accessed on 15 February 2017). (In portuguese) 
70. Barreiro, S.; Tomé, M.; Tomé, J. Modeling Growth of Unknown Age Even-aged Eucalyptus Stands. In Modeling Forest Production. Scientific Tools-Data Needs and Sources. Validation and Application, Proceedings of the International IUFRO Congress, Vienna, Austria, 19-22 April 2004; Hasenauer, H., Mäkelä, A., Eds.; U.S. National Library of Medicine: Bethesda, MD, USA, 2004; pp. 34-43.

71. Barreiro, S.; Rua, J.; Tomé, M. StandsSIM-MD: A Management Driven forest SIMulator. For. Syst. 2016, 25, 7. [CrossRef]

72. Monteiro, M.L.; Patrício, M.S. O castanheiro: Modelos de gestão. Revist. Florest. 1996, 9, 51-56. (In Portuguese)

73. González, J.R.; Palahí, M.; Pukkala, T. Integrating fire risk considerations in forest management planning in Spain-A landscape level perspective. Landsc. Ecol. 2005, 20, 957-970. [CrossRef]

74. Garcia-Gonzalo, J.; Pukkala, T.; Borges, J.G. Integrating fire risk in stand management scheduling. An application to Maritime pine stands in Portugal. Ann. Oper. Res. 2014, 219, 379-395. [CrossRef]

75. Ferreira, L.; Constantino, M.; Borges, J.G. A stochastic approach to optimize Maritime pine (Pinus pinaster Ait.) stand management scheduling under fire risk: An application in Portugal. Ann. Oper. Res. 2014, 219, 359-377. [CrossRef]

76. Rodríguez y Silvaa, F.; Molinaa, J.R.; González-Cabánb, A.; Machuca, M.A.H. Economic vulnerability of timber resources to forest fires. J. Environ. Manag. 2012, 100, 16-21. [CrossRef] [PubMed]

77. Kaloudis, S.; Costopoulou, C.I.; Lorentzos, N.A.; Sideridis, A.B.; Karteris, M. Design of forest management planning DSS for wildfire risk reduction. Ecol. Inform. 2008, 3, 122-133. [CrossRef]

78. McArthur, A.G. Fire Behaviour in Eucalypt Forests; Forestry and Timber Bureau: Canberra, Australia, 1967.

79. Van Wagner, C.E. Effect of slope on fires spreading downhill. Can. J. For. Res. 1988, 18, 818-820. [CrossRef]

80. Cumming, S.G. Forest type and wildfire in the Alberta boreal mixedwood: What do fires burn? Ecol. Appl. 2001, 11, 97-110. [CrossRef]

81. Castro, F.X.; Tudela, A.; SebastiÒ, M.T. Modeling moisture content in shrubs to predict fire risk in Catalonia (Spain). Agric. For. Meteol. 2003, 116, 49-59. [CrossRef]

82. Fernandes, P.; Luz, A.; Loureiro, C. Changes in wildfire severity from maritime pine woodland to contiguous forest types in the mountain of northwestern Portugal. For. Ecol. Manag. 2010, 260, 883-892. [CrossRef]

83. Schmidt, K.M.; Menakis, J.P.; Hardy, C.C.; Hann, W.J.; Bunnell, D.L. Development of Coarse-Scale Spatial Data for Wildland Fire and Fuel Management; Gen. Tech. Rep. RMRS-GTR-87; Department of Agriculture, Forest Service, Rocky Mountain Research Station: Fort Collins, CO, USA, 2002.

84. Kalabokis, K.D.; Omi, P.N. Reduction of fire hazard through thinning/residue disposal in the urban interface. Int. J. Wildland Fire 1998, 8, 29-35. [CrossRef]

85. Agee, J.K.; Skinner, C.N. Basic principles of forest fuels management. For. Ecol. Manag. 2005, $211,83-96$. [CrossRef]

86. Crecente-Campo, F.; Marshall, P.; Rodríguez-Soalleiro, R. Modeling non-catastrophic individual-tree mortality for Pinus radiata plantations in northwestern Spain. For. Ecol. Manag. 2009, 257, 1542-1550. [CrossRef]

87. Van Wangner, C.E. Conditions for the start and spread of crown fire. Can. J. For. Res. 1977, 7, 23-34. [CrossRef]

88. Finney, M.A. The challenge of quantitative risk analysis for wildland fire. For. Ecol. Manag. 2005, 211, 97-108. [CrossRef]

89. Anderson, H. Aids to Determining Fuel Models for Estimating Fire Behavior; General Technical Report INT-122; USDA Forest Service, Intermountain Forest and Range Experiment Station: Ogden, UT, USA, 1982; p. 22.

90. Raison, R.J.; Woods, P.V.; Khanna, P.K. Dynamics of fine fuels in recurrently burnt eucalypt forests. Aust. For. 1983, 46, 294-302. [CrossRef]

91. Keane, R.E.; Burgan, R.v.W.J. Mapping wildland fuels for fire management across multiple scales: Integrating remote sensing, GIS, and biophysical modeling. Int. J. Wildland Fire 2001, 10, 301-319. [CrossRef]

92. He, H.S.; Shang, B.Z.; Crow, T.R.; Gustafson, E.J.; Shifley, S.R. Simulating forest fuel and fire risk dynamics across landscapes-LANDIS fuel module design. Ecol. Model. 2004, 180, 135-151. [CrossRef]

93. Rico, M.; González, A. Social participation into regional forest planning attending to multifunctional objectives. For. Policy Econ. 2015, 59, 27-34. [CrossRef]

(C) 2017 by the authors; licensee MDPI, Basel, Switzerland. This article is an open access article distributed under the terms and conditions of the Creative Commons Attribution (CC BY) license (http:/ / creativecommons.org/licenses/by/4.0/). 